\title{
Assessment of electrocardiogram interpretation skills among Polish and English Division medical students
}

\author{
Ocena umiejętność interpretacji elektrokardiogramów wśród \\ polskich studentów medycyny oraz studentów z English Division
}

\author{
Marek Stopa ${ }^{1}$, Tomasz Tokarek ${ }^{1}$, Harison Sevenathan ${ }^{1}$, Izabela Pałasz ${ }^{1}$, \\ Mateusz Bogusławski ${ }^{1}$, Artur Dziewierz ${ }^{2}$, Zbigniew Siudak ${ }^{3}$, Dariusz Dudek ${ }^{1,2}$ \\ ${ }^{1} 2^{\text {nd }}$ Department of Cardiology and Cardiovascular Interventions, University Hospital, Krakow, Poland \\ ${ }^{2} 2^{\text {nd }}$ Department of Cardiology, Institute of Cardiology, Jagiellonian University Medical College, Krakow, Poland \\ ${ }^{3}$ Faculty of Medicine and Health Sciences, Jan Kochanowski University, Kielce, Poland
}

\begin{abstract}
8
Lekarz Marek Stopa jest absolwentem Wydziału Lekarskiego Collegium Medicum Uniwersytetu Jagiellońskiego w Krakowie. Obecnie odbywa staż lekarski w Szpitalu Uniwersyteckim w Krakowie. W przyszłości planuje rozpoczęcie szkolenia specjalizacyjnego z kardiologii. Do kręgu jego zainteresowań medycznych należy kardiologia zachowawcza, w szczególności nadciśnienie tętnicze i echokardiografia. W wolnym czasie dr Stopa tańczy, śpiewa, gotuje oraz gra na ukulele.
\end{abstract}

\section{Abstract}

Introduction. An electrocardiography (ECG) examination is one of the most frequently performed diagnostic tests. The correct interpretation of ECG, particularly in life-threatening scenarios (LTS) can influence decision-making on appropriate actions and so consequently can have an impact on the life and health of patients. The aim of this study was to evaluate ECG interpretation skills among a study population and to analyse factors determining their score.

Material and methods. ECG interpretation skills were assessed using a self-prepared questionnaire including questions about demographic data and 20 ECG problems arising from 17 cases. Six of these cases were LTS. Three questions evaluated basic understanding of heart rhythm, heart rate and axis. The survey was conducted via the internet. The study population consisted of 551 medical, nursing and emergency medicine students.

Results. The overall score among Polish medical students was higher than among nursing and emergency medicine students. English Division medical students scored almost the same as Polish medical students. Assessed in LTS, they performed better than the nursing students, but achieved similar results to those of the emergency medicine students. Analysis of Polish medical students showed that $4^{\text {th }}-6^{\text {th }}$ year students scored higher than their younger counterparts. $72 \%$ of medical students claimed to have self-educated themselves on ECG interpretation. This group had better results than students who had studied ECG only in the classroom. Less than $20 \%$ of students from each category of the study population felt that there were enough classes on ECG.

Conclusions. The level of ECG interpretative skills noted among medical students is unsatisfactory. Many factors influence ECG knowledge.

Key words: electrocardiography, students, life-threatening conditions, medical education

Folia Cardiologica 2018; 13, 5: 416-419

Address for correspondence: lek. Tomasz Tokarek, Il Oddział Kliniczny Kardiologii oraz Interwencji Sercowo-Naczyniowych, Szpital Uniwersytecki w Krakowie, ul. Kopernika 17, 31-501 Kraków, Poland, phone +48 12424 71 81, fax +48 12424 71 84, e-mail: tomek.tokarek@gmail.com 


\section{Introduction}

An electrocardiogram (ECG) is one of the most important diagnostic tests in medicine. It is used to detect abnormal heart rhythms and discover cardiac abnormalities causing chest pain [1, 2]. Its significance is underlined by the fact that ECG is performed on almost every patient admitted to an Emergency Department. Thus, students of all medical studies, including those of nursing and emergency medicine, should possess proper skills in interpreting ECG. Therefore, we aimed to assess the ECG interpretative skills of students of medicine (Polish and English Divisions), nursing, and emergency medicine.

\section{Materials and methods}

A self-prepared internet survey was designed to evaluate and compare competence in interpreting ECG among different groups. Participation in the study was voluntary, confidential and anonymous. The study was approved by the institutional ethics board. The survey was conducted among students at all 14 medical universities in Poland, and data was collected between January and April 2017. The survey consisted of three parts:

Part I - general information about participants: gender, field of study, name of university, year of study. The next nine closed questions focused on the history of ECG learning and an interest in cardiology. Participants also assessed their own ECG interpretation skills on a scale of 1-10 and were asked to evaluate the education level of ECG interpretation at their universities;

Part II - basics of ECG. This part consisted of three questions on basic ECG parameters. Based on three different ECG records, students were asked to define heart rate, the axis of the heart, and leading heart rhythm. In each question 4-5 answer options were given;

Part III - ECG cases. Seventeen ECGs with different pathologies were presented. Six of them were life-threatening scenarios (LTS): asystole, ventricle fibrillation, ventricle tachycardia, and myocardial infarction. All of them were open-ended questions and students were asked to define the main pathology seen in the ECG. The correct answers were verified by two independent cardiologists with clinical experience. There was no time limit. Quantitative variables were described using means and standard deviation. Categorical variables were presented as numbers and percentages. Differences between groups were tested using the Chi-square test and the Fisher's exact test for dichotomous variables and one-way ANOVA with post hoc Tukey test (for normal distribution with equal variance between groups) or the Kruskal-Wallis test (for non-normally distributed data) were applied for quantitative variables. The level of statistical significance was set at $p<0.05$. Multivariate logistic regression analysis with stepwise method was performed to find independent predictors of the level of knowledge of ECG interpretation. All collected characteristics were tested. Results were presented as odds ratios (OR) with 95\% confidence intervals (CI). All analyses were carried out using Statistica, version 12 (StatSoft, Inc., Tulsa, OK, USA).

\section{Results}

The survey obtained 551 completed questionnaires. The study group consisted of $283(51.4 \%)$ female and 268 $(48.6 \%)$ male participants. The results of the questionnaires are presented in Table 1. The group of Polish medical students, as the largest group, was chosen to analyse factors determining ECG knowledge. Students in their $4^{\text {th }}-6^{\text {th }}$ year did significantly better than those in their $1^{\text {st }}-3^{\text {rd }}$ year (overall score: $51 \%$ vs. $31 \%, p=0.001$, LTS: $41 \%$ vs. $25 \%$, $p=0.001)$. Students who self-evaluated their skills with a score $\geq 5 / 10$ scored better than those with $<5 / 10$. Students who had learned about ECG for more than one year had a better overall score than the rest (50\% vs. 38\%, $p=0.001)$. In addition, students who had learned about ECG by themselves did better than the others (overall score: $49 \%$ vs. $37 \%$; LTS: $40 \%$ vs. $30 \%, p=0.001$ ). On the other

Table 1. Results of the electrocardiography (ECG) interpretation questionnaire

\begin{tabular}{|c|c|c|c|c|c|}
\hline Parameter & $\begin{array}{l}\text { Polish medical } \\
\qquad N=316\end{array}$ & $\begin{array}{l}\text { Emergency } \\
\qquad N=123\end{array}$ & $\begin{array}{l}\text { Nursing } \\
\mathrm{N}=58\end{array}$ & $\begin{array}{l}\text { English medical } \\
\qquad N=54\end{array}$ & p \\
\hline Overall score [\%] & $145(46 \%)$ & $46(37 \%)$ & $13(22 \%)$ & $26(49 \%)$ & 0.001 \\
\hline Average score of basic ECG skills [\%] & $243(77 \%)$ & $77(63 \%)$ & $27(46 \%)$ & $37(69 \%)$ & 0.001 \\
\hline Average score for life-threatening scenarios [\%] & $117(37 \%)$ & $47(38 \%)$ & $13(23 \%)$ & $22(40 \%)$ & 0.001 \\
\hline Students who self-learned ECG [\%] & $223(72 \%)$ & $91(74 \%)$ & $31(53 \%)$ & $27(50 \%)$ & 0.02 \\
\hline $\begin{array}{l}\text { Students who thought there were sufficient ECG } \\
\text { classes in University [\%] }\end{array}$ & $38(12 \%)$ & $21(17 \%)$ & $2(3.5 \%)$ & $10(18.5 \%)$ & 0.2 \\
\hline Average duration of ECG learning [years] (mean \pm SD) & $1.99 \pm 1.28$ & $2.06 \pm 2.26$ & $1.52 \pm 2.62$ & $2.40 \pm 1.20$ & 0.08 \\
\hline
\end{tabular}


hand, there was no difference between students who felt that there were enough ECG classes compared to those who felt that there were insufficient ECG classes ( $45 \%$ vs. $46 \%, p=0.8$ ). Members of cardiology study groups performed significantly better than non-members (overall score: $57 \%$ vs. $43 \%, p=0.001$; LTS: $51 \%$ vs. $35 \%, p=0.001$ ). Students who planned to specialise in cardiology had a higher score than the others (overall score: $62 \%$ vs. 44\%; LTS: $58 \%$ vs. $35 \%, p=0.001)$. In logistic regression analysis, self-evaluated skills with a score $\geq 5 / 10$ (OR 3.31, 95\% Cl: $2.55-4.07, p=0.01$ ) and a plan to specialise in cardiology (OR 2.87, 95\% Cl: 1.36-4.38, $p=0.001$ ) were both identified as independent predictors of knowledge of ECG interpretation.

\section{Discussion}

Our results suggest that ECG interpretation among Polish medical students is unsatisfactory in all of the examined fields of study. Poor results were noticeable especially when confronted with LTS. However, many modifiable factors could improve ECG knowledge among students. Poor results have also been shown in similar studies conducted in Poland. Kopeć et al. reported an average percentage of correct answers of $66 \%$ [3]. In the study by Pudło et al. this percentage varied from $45.5 \%$ to $62 \%$ [4]. In our study these results were even worse. We believe that this may be related to the presence of open-ended questions in our questionnaire. In our study, the overall score for emergency medicine students was worse than for medical students, but they scored similarly when it comes to LTS. This is important, because paramedics are trained specially to recognise emergency situations [5]. The results of nursing students were the worst of all the groups. In Poland, nursing students are not required to be able to interpret ECG [6]. In other countries, ECG interpretative skills are poor and need to be improved, not only for students, but also for graduated doctors, paramedics and nurses [7-9]. Ours is the first study to have analysed the ECG knowledge of foreign medical students studying in Poland. We have shown that the ECG knowledge of such students is similar to that of Polish students of medicine, although their classes are in a different language. Unsurprisingly, older and more experienced students had better ECG interpretative skills than their younger counterparts. This relationship has been reported not only for students $[3,4]$ but also for residents $[10,11]$ by previous studies. Higher self-evaluation of ECG skills was a factor determining a better score in our questionnaire. Our study showed that most students had learned ECG on their own. Interestingly, only medical students preferred this mode of education, which resulted in them having a better score compared to students who had learned ECG only during classes. Self-learning has also been found to be a factor leading to improved ECG knowledge in other Polish studies [3, 4]. Students who were interested in cardiology had better results than the others. Most of the students from all groups declared that there had not been enough ECG activities during their studies. These results suggest that there is a need to improve not only the quality, but also the quantity, of ECG classes.

\section{Limitations of the study}

The most important limitation of our study was that the questionnaire was anonymous and that only volunteers participated. Furthermore, there were no time limits for completing the questionnaire, so participants were able to consult the internet or books about ECG.

\section{Conclusions}

Polish medical students possess insufficient knowledge regarding ECG interpretation, especially when interpreting ECG in life-threatening scenarios. Many factors, some of which could be modified, influence the level of ECG knowledge among students.

\section{Conflict of interest(s)}

The authors declare no conflict of interest.

\section{Streszczenie}

Wstęp. Badanie elektrokardiograficzne (EKG) jest jednym z najczęściej wykonywanych testów diagnostycznych. Prawidłowa interpretacja zapisu EKG, zwłaszcza w sytuacjach zagrożenia życia, może wpływać na decyzję o wdrożeniu prawidłowego postępowania, a w konsekwencji - na zdrowie i życie pacjentów. Celem badania była ocena umiejętności interpretacji zapisu EKG wśród studentów kierunków medycznych oraz analiza czynników mających wpływ na ich rezultaty.

Materiały i metody. Umiejętność interpretacji EKG zbadano za pomocą własnego kwestionariusza zawierającego pytania demograficzne oraz 20 pytań na temat EKG, w tym 17 przypadków klinicznych. Sześć z nich było przykładami stanów zagrożenia życia. Trzy pytania dotyczyły podstawowych parametrów EKG: częstości pracy serca, osi serca, pochodzenia rytmu serca. Ankietę przeprowadzono przez Internet. Zbadano 551 studentów kierunków lekarskiego, pielęgniarstwa oraz ratownictwa medycznego. 
Wyniki. Średni wynik osiagnięty przez polskich studentów medycyny był lepszy niż wynik studentów pielęgniarstwa i medycyny ratunkowej. Studenci English Division osiągnęli podobne wyniki. Polscy studenci medycyny byli lepsi od studentów pielęgniarstwa w rozpoznawaniu stanów zagrożenia życia, ale osiągnęli podobne rezultaty do studentów ratownictwa medycznego. Wśród polskich studentów medycyny studenci na IV-VI roku uzyskali lepsze wyniki niż studenci z lat I-III. Samonauczanie EKG zadeklarowało $72 \%$ studentów kierunku lekarskiego. Ta grupa osiągnęła lepsze wyniki niż studenci, którzy EKG uczyli się wyłącznie w czasie zajęć na studiach. Mniej niż 20\% studentów z każdego kierunku uważało, że zajęć na temat EKG jest wystarczająco dużo.

Wnioski. Stan wiedzy studentów kierunków medycznych w Polsce jest niski. Wiele czynników wpływa na umiejętność interpretacji zapisu EKG przez studentów.

Słowa kluczowe: elektrokardiografia, studenci, sytuacje zagrożenia życia, edukacja medyczna

Folia Cardiologica 2018; 13, 5: 416-419

\section{References}

1. Fisch C. Evolution of the clinical electrocardiogram. J Am Coll Cardiol. 1989; 14(5): 1127-1138, doi: 10.1016/0735-1097(89)90407-5.

2. Kadish AH, Buxton AE, Kennedy HL, et al. American College of Cardiology, American Heart Association, American College of Physicians, American Society of Internal Medicine Task Force, International Society for Holter and Noninvasive Electrocardiology. ACC/AHA clinical competence statement on electrocardiography and ambulatory electrocardiography: A report of the ACC/AHA/ACP-ASIM task force on clinical competence (ACC/AHA Committee to develop a clinical competence statement on electrocardiography and ambulatory electrocardiography) endorsed by the International Society for Holter and noninvasive electrocardiology. Circulation. 2001; 104(25): 3169-3178, doi: 10.1161/circ.104.25.3169, indexed in Pubmed: 11748119.

3. Kopeć G, Magoń W, Hołda M, et al. Competency in ECG interpretation among medical students. Med Sci Monit. 2015; 21: 3386-3394, doi: 10.12659/msm.895129, indexed in Pubmed: 26541993.

4. Pudło J, Wierdak M, Macioł K, et al. The comparison of 4 th, 5 th and 6 th year medical students knowledge of rules and practical skills in the interpretation of electrocardiograms at Jagiellonian University. Przegl Lek. 2012; 69(4): 143-148, indexed in Pubmed: 23029708.

5. Dziennik Ustaw z 2006 r., nr 191, poz. 1410: ustawa z dnia 8 września 2006 r. o Państwowym Ratownictwie Medycznym (The act of 8 September 2006 on Emergency Medical Services, Journal of Laws of the Republic of Poland). Warszawa, 2006.
6. Dziennik Ustaw z 2012 r., poz. 631: rozporządzenie Ministra Nauki i Szkolnictwa Wyższego z dnia 9 maja 2012 r. w sprawie standardów kształcenia dla kierunków studiów: lekarskiego, lekarsko-dentystycznego, farmacji, pielęgniarstwa i położnictwa (Regulation of the Minister of Science and Higher Education of 9 May 2012 on the standards of education of the following fields of study: medicine, medicine and dentistry, pharmacy, nursing, midwifery). Warszawa, 2012.

7. Jablonover RS, Lundberg $\mathrm{E}$, Zhang $\mathrm{Y}$, et al. Competency in electrocardiogram interpretation among graduating medical students. Teach Learn Med. 2014; 26(3): 279-284, doi: 10.1080/10401334.2014. 918882, indexed in Pubmed: 25010240.

8. Lever NA, Larsen PD, Dawes M, et al. Are our medical graduates in New Zealand safe and accurate in ECG interpretation? N Z Med J. 2009; 122(1292): 9-15, indexed in Pubmed: 19448769.

9. Goodridge E, Furst C, Herrick J, et al. Accuracy of cardiac rhythm interpretation by medical-surgical nurses: a pilot study. J Nurses Prof Dev. 2013; 29(1): 35-40, doi: 10.1097/NND.0b013e31827d0c4f, indexed in Pubmed: 23486155.

10. Crocetti M, Thompson R. Electrocardiogram interpretation skills in pediatric residents. Ann Pediatr Cardiol. 2010; 3(1): 3-7, doi: 10.4103/0974-2069.64356, indexed in Pubmed: 20814469.

11. de Jager J, Wallis L, Maritz D. ECG interpretation skills of South African emergency medicine residents. Int J Emerg Med. 2010; 3(4): 309-314, doi: 10.1007/s12245-010-0227-3, indexed in Pubmed: 21373298. 